\title{
PENERAPAN SISTEM TUMPANG SARI PADA BUDIDAYA TANAMAN KAKAO DI DESA BANDAR MASILAM I KECAMATAN BANDAR MASILAM KABUPATEN SIMALUNGUN SUMATERA UTARA
}

\author{
Hot Setiado ${ }^{1)}$, Emmy Harso Kardhinata ${ }^{2)}$, Lollie Agustina P. Putri ${ }^{3)}$ \\ ${ }^{1)}$ Fakultas Pertanian, Universitas Sumatera Utara \\ Email: setiado@yahoo.com \\ ${ }^{2)}$ Fakultas Pertanian, Universitas Sumatera Utara \\ Email: harso@usu.ac.id \\ ${ }^{3)}$ Fakultas Pertanian, Universitas Sumatera Utara \\ Email: lollie.agustina@usu.ac.id
}

\begin{abstract}
Abstrak
Tim Universitas Sumatera Utara (USU) mengusulkan kegiatan pengabdian pada masyarakat (PPM) ini di Desa Bandar Masilam I atas dasar keterbatasan-keterbatasan yang dimilikinya. Desa ini terletak di bagian tengah Provinsi Sumatera Utara, sekitar $145 \mathrm{~km}$ dari kota Medan dan dapat ditempuh dengan kendaraan roda 2 dan roda 4. Kondisi jalan ke desa yang kurang baik menyebabkan waktu tempuh dari Medan dapat mencapai 4 jam. Letak desa diantara perkebunan kelapa sawit milik pemerintah maupun swasta. Masyarakat desa Bandar Masilam I sebagian besar petani dan sebagai buruh di perkebunan yang ada di sekitarnya. Sebagian masyarakat yang memiliki ladang dan lahan pekarangan telah memanfaatkan dengan menanami kelapa sawit. Kualitas sawit yang kurang baik menyebabkan harga jual menjadi tidak menentu, sehingga sebagian masyarakat sudah mencoba beralih ke komoditi kakao. Gapoktan Serumpun, kelompok tani Mandiri, Lestari dan Mekar Sari telah mencoba menanam kakao dengan bibit yang bersertifikat dan berkualitas. Sebagian bibit kakao bersertifikat berasal dari pengabdian pada masyarakat Universitas Sumatera Utara tahun 2017. Pendapatan masyarakat yang masih rendah sebagai salah satu kendala dalam budidaya kakao karena harus menunggu waktu panen yang cukup lama. Perlu dilakukan langkah untuk menambah pendapatan masyarakat dari lahan kakao yang mereka miliki. Tim pengabdian pada masyarakat USU mencoba memberikan solusi dengan cara memberikan bantuan bibit tanaman tumpangsari yang berkualitas dan bersertifikat untuk meningkatkan pendapatan petani/pekebun. Selain itu juga diberikan teknologi perawatan terhadap tanaman tumpangsari dan tanaman utama yang tepat kepada kelompok tani. Dari usaha yang dilakukan ini diharapkan kelompok tani yang menjadi mitra tim dari USU ini akan menjadi pelopor dalam menghasilkan produksi kakao yang berkualitas dan juga memperoleh pendapatan sampingan dari tanaman tumpangsari.
\end{abstract}

Kata Kunci: Komoditi, Mandiri, Kelapa Sawit.

\section{PENDAHULUAN}

Desa Bandar Masilam I, Kecamatan Bandar Masilam, Kabupaten Simalungun terletak di bagian tengah Sumatera Utara. Jarak dari Medan (ibukota provinsi sekitar $145 \mathrm{~km}$ yang dapat ditempuh dengan kendaraan bermotor (mobil dan sepeda motor) dengan waktu lebih kurang 2,5 jam. Desa Bandar Marilam I berada di sekitar perkebunan kelapa sawit baik milik pemerintah maupun swasta. Dengan desa yang berada jauh di pedalaman,dan kondisi jalan menuju desa yang kurang baik, desa ini cukup sulit diakses sehingga jalur transportasi dari dan menuju desa ini kurang lancar. Kondisi ini merupakan salah satu penyebab perekonomian adi desa ini menjadi lambat disamping faktor-faktor lainnya seperti tingkat pendidikan, fasilitas umum, dan lain-lain.

Sebagian besar masyarakat hidup sebagaipetani tanaman pangan dan palawija, peternak, petani perkebunan dan sebagai 
buruh di perkebunan yang ada di sekitarnya. Profesi sebagai petani dan pekebun dengan luasan lahan yang terbatas menyebabkan pendapatan masyarakat juga tidak begitu tinggi. Kebutuhan hidup yang semakin besar menyebabkan tingkat kesejahteraan masyarakat di desa tersebut cukup rendah. Sebahagian petani perkebunan memiliki kebun kelapa sawit namun tidak begitu luas, dan hasil yang rendah sehingga tidak dapat memenuhi kebutuhan hidup. Oleh karena itu sebagian masyarakat petani kelapa sawit sudah berusaha mengkonversi lahan sawit menjadi kakao sebagaimana yang pernah mereka lakukan pada era 1990-an. Saat ini masayarakat telah membentuk kelompok tani yang mengusahakan tanaman kakao. Alasan masyarakat menanam kakao antara lain adalah harga sawit yang tidak menentu dan tidak pasti karena masih harus bergantung pada banyak faktor, salah satunya adalah keberadaan tengkulak.

Gabungan Kelompok Tani (Gapoktan) Serumpun dan Kelompok Tani Mandiri, Kelompok Tani Lestari, Kelompok Tani Mekar Sari merupakan empat kelompok yang mencoba beralih menanam komoditi kakao. Alasan mereka menanam kakao karena dapat memanfaatkan lahan pekarangan. Bercermin dari kegagalan budidaya kakao masa lalu yang menggunakan bibit dari kakao yang tidak jelas tahun ini dengan bantuan Lembaga Pengabdian Masyarakat USU masyarakat telah menerima bantuan bibit kakao bersertifikat. Selain itu juga memperoleh bantuan peralatan perawatan tanaman kakao seperti gunting, gergaji, arit, sprayer dan lainlain serta penyuluhan budidaya dan perawatan kakao. Dengan demikian diharapkan segala bantuan ini dapat meningkatkan pendapatan masyarakat guna memenuhi kebutuhan hidup yang semakin meningkat.Saat ini masyarakat baik yang tergabung dalam kelompok tani maupun tidak, sudah ada yang mencoba menanam kakao dengan bibit yang bersertifikat baik di lahan perladangan maupun di lahan pekarangan.

\subsection{Permasalahan Mitra}

Tanaman kakao dari gapoktan Serumpun dan kelompok tani Mandiri, Mekar Sari, Lestari dengan menggunakan bibit bersertifikat dari LPPM USU sudah ditanam di berbagai lokasi baik ahan perladangan maupun lahan pekarangan. Sebagian bibit masih berada pada lahan persemaian dan siap untuk dibagikan kepada masyarakat yang beum memperoleh bibit. Sebagian anggota kelompok tani adalah petani yang yang bergantung pada hasil dari lahan pekarangan dan perladangan. Perlu upaya pemanfaatan lahan seoptimal mungkin guna meningkatkan pendapatan masyarakat di masa mendatang.

Metode tumpang sari antara kakao dengan tanaman lain yang bernilai ekonomi merupakan salah satu usaha yang untuk membantu masyarakat memperoeh hasil tambahan dari lahan pekarangan maupun perladangan mereka selain dari tanaman pokok yaitu kakao.Melihat kondisi ini perlu dilakukan upaya perbaikan kedepan yaitu melalui peningkatan pengetahuan petani tentang penggunaan benih yang baik, perbaikan budidaya tanaman kakao dan bantuan berupa peralatan budidaya, bibit tanaman pelindung, pupuk dan pestisida; terutama penerapan sistem tumpangsari.

Terbatasnya pengetahuan masyarakat tentang hal-hal yang telah dikemukakan di atas mendorong tim dari Universitas Sumatera Utara untuk memberikan pendidikan penerapan sistem tumpangsari yang tepat pada kakao, teknik pembibitan dengan benih unggul bersertifikat, dan teknikbudidaya kakao yang baik dan benar serta memberikan bantuan kepada masyarakat petani kakaoperalatan budidaya, pupuk dan pestisida. Dengan peningkatan pengetahuan tentang kultur teknis yang sesuai diharapkan ke depan dapat diperoleh tanaman kakao yang berproduksi tinggi dan berkualitas baik sehingga akhirnya dapat meningkatkan pendapatan masyarakat petani kakao di daerah tersebut. 
Universitas Sumatera Utarasebagai perguruan tinggi yang memiliki sumberdaya manusia yang memiliki ilmu pengetahuan di bidang budidaya pertanian dan agribisnis memiliki kemampuan untuk merubah perilaku masyarakat untuk mengembangkan perekonomiannya. Sesuai dengan visinya 'Pada tahun 2025 menjadiUniversitas yang unggul di bidang akademik, ilmu pengetahuan dan teknologi dalam menghasilkan lulusan yang inovatif, berkepribadian dan mandiri'kami dari perguruan tinggi USU melalui PPM program IbM tahun 2018 akan berusaha mengatasi permasalahan tersebut di atas melalui pelaksanaan pelatihan/ sosialisasi/ pendidikan iptek bagi masyarakat Desa Bandar Masilam I dalam penerapan sistem tumpangsari, teknologi pembibitan kakao dan budidaya kakao guna menghasilkan tanaman kakao yang baik dan berproduksi tinggi guna meningkatkan pendapatan masyarakat petani kakao.

\section{TARGET LUARAN}

Untuk menghasilkan tanaman kakao yang baik tidak hanya dimulai dengan pemilihan benih yang baik dan terjamin kualitasnya, namun juga pengelolaan tanaman lebih lanjut, antara lain: sistem tumpangsari yang tepat, pengendalian hama terpadu, sistem naungan yang baik, dan sistem pemangkasan yang benar. Pendekatan pengelolaan baru, berdasar praktik budidaya agronomis yang sehat dan strategi pengelolaan hama dan penyakit terpadu (PHPT), harus segera diterapkan dan dikembangkanuntuk membantu petani mengoptimalkan produksi kakaonya. Petani akan dapat mengharapkan hasil lebih tinggi secara nyata jika pendekatan ini diterapkan dengan lengkap dan benar.

Apa yang telah dialami oleh gapoktan Serumpun, kelompok tani Mandiri, kelompok tani Lestari, kelompok tani Mekar Sari merupakan suatu bukti bahwa pengelolaan tanaman yang kurang baik akan menghasilkan tanaman kakao yang kurang baik sehingga pertumbuhan dan produksinya rendah.
Langkah-langkah yang telah dilaksanakan bersama petani kakao di desa lokasi kegiatan antara lain adalah;

(a) Pembibitan kakao dengan benih unggul bersertifikat,

(b) Penyambungan tanaman kakao yang kurang berkualitas dengan pucuk tanaman kakao unggul melalui teknik sambung samping,

(c) Pemangkasan kakao,

(d) Pengendalian gulma, meliputi : pengendalian gulma tanpa bahan kimia dan pengendalian gulma dengan herbisida,

(e) Pemupukan.

Usaha di atas masih belum cukup untuk tujuan meningkatkan pendapatan masyarakat petani kakao. Untuk itu diperlukan teknik budidaya kakao dengan sistem tumpangsari dengan tanaman yang bernilai ekonomi guna menambah pendapatan masyarakat disamping hasil dari kakao. Teknik tumpangsari yang diterapkan adalah melalui tumpang sari 3 lapis yaitu:

a) Penggunaan tanaman pelindung kakao yang bernilai ekonomi

Jenis tanaman pelindung yang akan digunakan adalah durian cangkok, sirsak dan petai.

b) Pemanfaatan ruang antara tanaman kakao dengan menanami tanaman sela

Jenis tanaman yang dipilih adalah merica perdu. Tanaman ini sudah banyak dibudidayakan di desa setempat dengan hasil yang sangat baik.

c) Pemanfaatan lahan kosong antara tanaman sela dan tanaman kakao.

Jenis tanaman yang dipilih adalah kencur. Tanaman kencur merupakan tanaman yang pertumbuhan menyebar ke samping dengan tinggi tanaman tidak lebih dari 10 $\mathrm{cm}$ sehingga tidak akan mempengaruhi pertumbuhan kakao. Disamping itu permintaan kencur di pasar sangat tinggi.

Dengan metode tumpangsari 3 lapis ini diharapkan masyarakat petani akan memperoleh hasil dari tanaman pelindung 
(durian, sirsak dan petai), tanaman sela (merica perdu) dan tanaman cover (kencur) sehingga dapat menambah pendapatan selain dari tanaman utama yaitu kakao.

\section{METODE PELAKSANAAN}

Pelaksanaan pengabdian pada masyarakat dilakukan dengan metode ceramah, diskusi dan praktek langsung di lapangan. Tahapan pelaksanaan kegiatan tersbut adalah sebagai berikut :

\subsection{Penyiapan bahan tanaman tumpangsari}

Langkah pertama yang dilakukan adalah penyiapan bahan tanam. Bahan tanam berupa bibit tanaman durian, petai, sirsak, kencur, kunyit. Bahan tanam durian dan sirsak berasal dari hasil perbanyakan sambung pucuk; petai berasal dari perbanyakan secara okulasi; merica perdu berasal dari hasil perbanyakan secara stek. Alasan menggunakan tanaman tumpangsari berasal dari perbanyakan nonbiji adalah agar cepat menghasilkan. Untuk tanaman kunyit, kencur ditanam dengan menggunakan rimpang.

\subsection{Penanaman tanaman tumpangsari}

Pembuatan lubang tanam bertujuan untukmenyediakan lingkungan perakaran yang optimal bagi bibit, baik secara fisik, kimia, maupun biologi. Tanah di lapangan sering terlalu padat bagi perakaran bibit untuk berkembang dengan baik setelah dipindahkan daritanah gembur di dalam polibag. Karena itu, kondisi yangrelatif sama dengan kondisi di pembibitan perlu disiapkandi lapangan dengan cara mengolah tanah secara minimalatau dengan cara membuat lubang tanam. Dengan demikian diharapkan tanaman dapat beradaptasi denganbaik pada awal pertumbuhannya di lapangan.Ukuran lubang tanam umumnya $60 \times 60 \times 60 \mathrm{~cm}$. Semua kegiatan di atas dilaksanakan oleh anggota kelompok secara bergantian yang diatur oleh Ketua Kelompok Tani. Mengingat hasil dari sistem tumpangsari ini akan diserahkan sepenuhnya kepada anggota kelompok tani maka tidak ada pembayaran atau upah yang diberikan kepada anggota kelompok tani yang melaksanakan pekerjaan tersebut. Pelaksanaan kegiatan ini diiringi dengan penjelasan-penjelasan yang dianggap perlu untuk memberikan tambahan pengetahuan kepada petani.

\section{HASIL LUARAN YANG DICAPAI}

Pelaksanaan kegiatan pengabdian di desa Bandar Masilam I dilakukan melalui beberapa tahap, antara lain peninjauan lokasi, sosialisasi program kepada Kepala Desa dan aparat serta kelompok tani, persiapan bahanbahan tanaman, pengiriman bahan-bahan tanaman ke lokasi, pembagian tanaman kepada kelompok tani dan masyarakat, penanaman tanaman sela dan tanaman pelindung kakao.

1. Peninjauan lokasi dan Sosialisasi program

Peninjauan lokasi dan sosialisasi dilaksanakan dalam waktu bersamaan dengan menghadirkan kepala desa dan aparat berserta kelompok tani melalui pertemuan di rumah salah satu warga pemimpin kelompok tani. Dalam sosialisasi ini dijelaskan kepada masyarakat tentang program yang akan dilaksanakan serta dampak yang akan dirasakan oleh masyarakat petani kakao.

2. Pembagian tanaman

Tanaman pelindung untuk kakao diserahkan kepada kelompok tani antara lain :
a. Kelapa pandan (Cocos nucifera) 50 batang
b. Durian unggul (Durio zibethinus) 100 batang
c. Sirsak (Annona muricata) 100 batang
d. Petai (Parkia speciosa) 100 batang
e. Jambu madu (Syzigium aqueum) 20 batang
Tanaman sela
a. Lada perdu 500 batang
b. Kencur (banyak)

3. Penanaman tanaman sela dan tanaman Pelindung 
Sebagian petani kakao yang telah menerima bibit tanaman peindung segera menanam di lahan masing-masing.

Penanaman Kencur

Sela-sela yang ada diantara tanaman kakao dan merica perdu masih dapat dimanfaatkan untuk tanaman lainnya. Jenis tanaman yang cocok adalah tanaman yang selama pertumbuhan dan perkembangannya tidak mengganggu tanaman kakao dan merica perdu. Gangguan tanaman terhadap tanaman lainnya bisa berupa persaingan unsur hara, sinar matahari, udara, air, ruangan dan lain-lain. Oeh karena itu dipilih tanaman kencur (Kaempferia galanga).

Bantuan bibit kencur diberikan kepada petani yang telah bergabung dengan kelompok tani dan menanam kakao dengan tumpang sari merica perdu serta pohon pelindung kakao yang telah ditanam sebelumnya. Diharapkan kencur ini dapat berkembang dengan baik dan menjadi salah satu sumber pendapatan tambahan disamping kakao, merica perdu dan buah-buahan dari pohon pelindung kakao.

4. Penambahan bibit kakao

Upaya yang dilakukan Tim Pengabdian kepada Masyarakat USU dalam peningkatan pendapatan masyarakat melalui teknik tumpang sari kakao mendapat sambutan baik dari masyarakat. Petani yang belum bergabung dengan kelompok beramairamai mendaftarkan diri sehingga diperlukan tambahan bibit kakao. Untuk memenuhi kebutuhan ini dilakukan penambahan bibit kakao sambung pucuk dari tanaman kakao unggul sebanyak 100 batang. Dengan demikian kebutuhan tanaman tumpang sari (merica perdu) juga bertambah sebanyak 550 batang, sehingga dilakukan penambahan dan telah dibagikan kepada masyarakat.

5. Konsolidasi dengan Petani

Keberlangsungan program pengabdian merupakan hal yang sangat penting. Banyak program pengabdian yang terhenti setelah pelaksanaan berakhir. Untuk itu diperlukan konsolidasi dengan petani dengan membentuk tim yang bertugas untuk memantau perkembangan dan keangsungan program pengembangan kakao ini. Ketua kelompok tani dibantu beberapa anggota bertanggung jawab untuk memimpin program pengembangan kakao. Permasalahan yang timbul dalam peaksanaan program dilaporkan pada Tim Pengabdian Masyarakat USU untuk diberi masukan dalam pemecahannya.

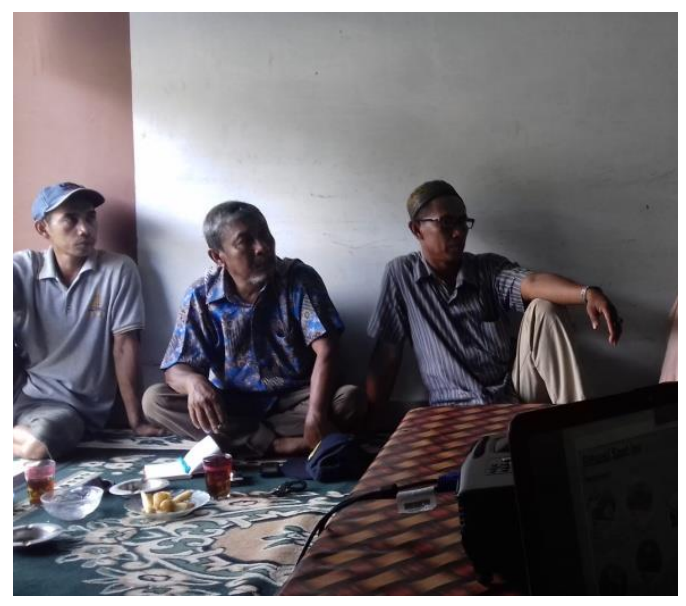

Gambar 1. Kepala Desa Bandar Masilam, dan Penyuluh Pertanian, dan Masyarakat Kelompok Tani Kakao. 
Hot Setiado. et.al. Penerapan Sistem Tumpang Sari Pada Budidaya Tanaman Kakao Di Desa Bandar Masilam I Kecamatan Bandar Masilam Kabupaten Simalungun Sumatera Utara

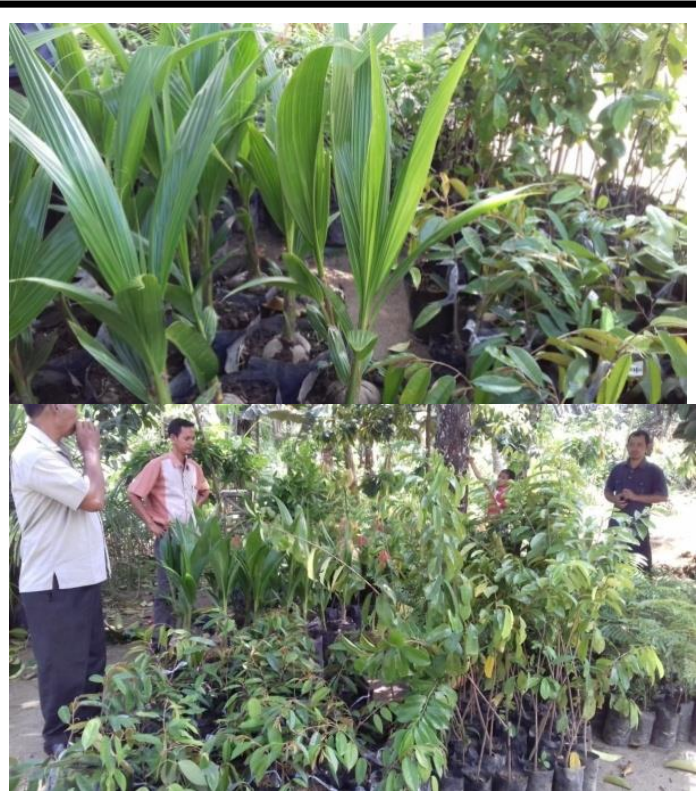

Gambar 2. Kelapa pandan, durian unggul sirsak dan petai

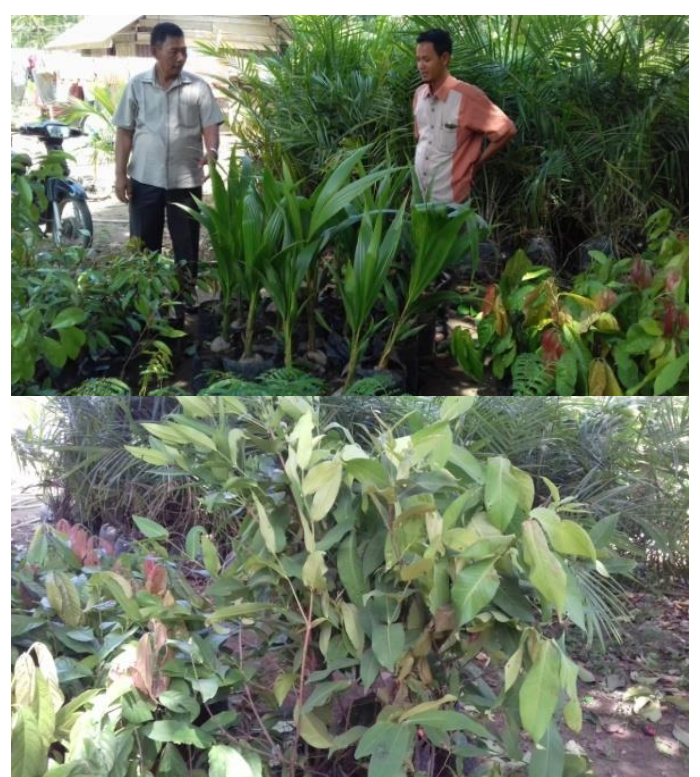

Gambar 3. Kelapa pandan, durian unggul, kakao, dan Jambu madu

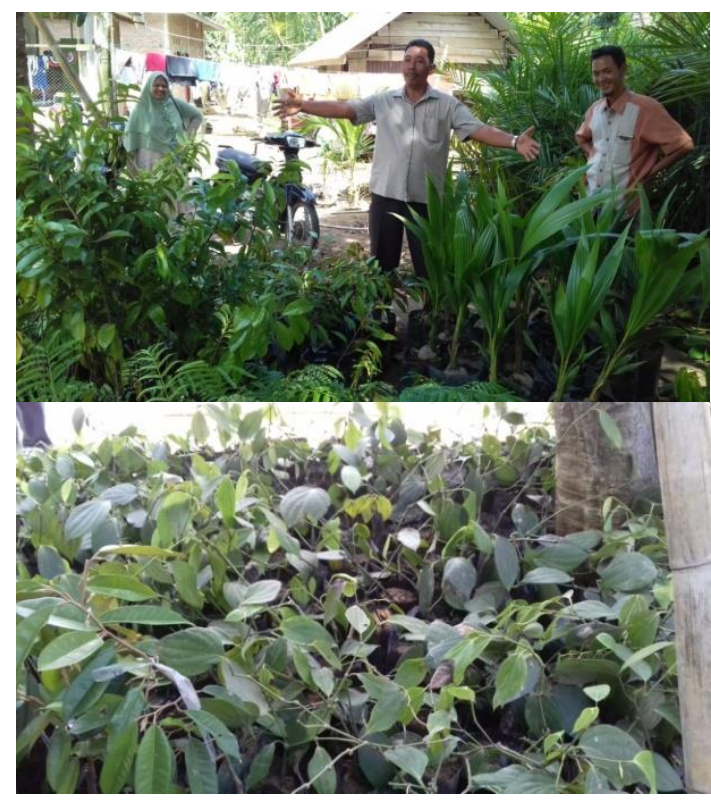

Gambar 4. Cerminan kebahagiaan kelompok tani menerima bibit tanaman lada perdu

\section{KESIMPULAN DAN SARAN}

Masih diperlukan tanaman pelindung dan tanaman sela yang lebih banyak mengingat besarnya minat masyarakat terhadap program pengabdian ini. Masyarakat telah mengenal sebelumnya potensi lada perdu, namun belum mampu untuk membeli dan menanam sebagai tanaman pekarangan. Melalui program ini diharapkan masyarakat terbantu dalam hal pengadaan bibit serta dapat memanfaatkan lahan sela kakao untuk penambah pendapatan masyarakat serta pengembangan bibit di masa yang akan datang. Program pengembangan kakao tumpang sari dalam rangka peningkatan pendapatan masyarakat sangat diminati oleh petani sehingga banyak petani yang bergabung dengan kelompok untuk memperoleh bantuan bibit kakao dan bibit tanaman sela.

\section{UCAPAN TERIMA KASIH}

Kegiatan pengabdian masyarakat yang telah dilaksanakan telah dapat diselesaikan dengan dan didapat hasil yang diharapkan dapat diadopsi oleh masyarakat. Dalam pelaksanaan kegiatan ini, tim peneliti banyak mendapat bantuan dari bebagai kalangan, 
Hot Setiado. et.al. Penerapan Sistem Tumpang Sari Pada Budidaya Tanaman Kakao Di Desa Bandar Masilam I

Kecamatan Bandar Masilam Kabupaten Simalungun Sumatera Utara

sehingga kegiatan pengabdian ini dapat terlaksana. Sehubungan dengan hal tersebut, tim peneliti mengucapkan terima kasih kepada LPPM USU yang telah membiayai kegiatan ini.

\section{DAFTAR PUSTAKA}

Badan Litbang Pertanian. 2007. Prospek dan ArahPengembangan Agribisnis Kakao. Ed II. 26 hal.

Bakri, A.H., FX Soegabyo dan P. Sembiring, 1989. Kelapasebagai naungan kakao di PT. P.P. Londom SumateraIndonesia. Kump. Makalah Seminar Sehari Tumpangsari Kelapa-Kakao. Pusat Penelitian Bandar Kuala, SumateraUtara, 18 Januari 1989. 25p

[BPS] Badan Pusat Statistik. 2016. Data statistik kependudukan Desa Bandar Masilam I. Kecamatan Bandar Huluan dalam angka.

Direktorat Jendral Perkebunan. 2008. Gerakan PeningkatanProduksi dan Mutu Kakao Nasional. Bahan presentasiDirjenbun pada bulan Nopember 2008 di hadapan Tim

Itjen Deptan. 26 hal.

Google maps. 2014. Peta interpretasi wilayah Bandar Masilam I beserta tutupannya. (diakses pada 2 Fabruari 2017).

Elna Karmawati, dkk. 2010. Budidaya dan Pasca Panen Kakao. Pusat Penelitian dan Pengembangan Perkebunan.

Firdausil AB, Nasriati, A. Yani. 2008. Teknologi Budidaya Kakao.Balai Besar Pengkajian dan Pengembangan TeknologiBudidaya dan Pasca Panen KAKAO 93Pertanian, Badan Penelitian Dan PengembanganPertanian. 26p.

Hatta Sunanto. 1994. Cokelat, Pengolahan Hasil dan Aspek Ekonominya. Kanisius.
Rijadi Subiantoro. 2009. Teknik Pembibitan Tanaman Kakao. Politeknik Negeri Lampung.

Rubyo, R., Siswanto, S. 2010. Peningkatan Produksi dan Pengembangan Kakao (Theobroma cacao L. ). di Indonesia. Jurnal Tanaman Industri dan Penyegar Vol 3, No 1 (2012).

Siagian, I.P.S., Balonggu, S., Jonatan, G. 2014. Pertumbuhan Bibit Kakao (Theobroma cacaoL.) dengan Pemberian Pupuk NPKdan Hayati. Jurnal Online Agroekoteknologi . ISSN No. 2337-6597, Vol.2, No.2 : 447459, Maret 2014.

Wood, G.A.R, 1975, Cocoa Tropical Agriculture Series, 3 Ed,London, Longmans. 